\title{
Impact of compaction test on mineral texture breakage in Tanjung Bunga Beach, Makassar
}

\author{
Hamid Umar ${ }^{1, *}$, Dadang A. Suriamihardja ${ }^{2}$, Lawalenna Samang ${ }^{3}$, and Ulva Ria $\operatorname{Irfan}^{1}$ \\ ${ }^{1}$ Hasanuddin University, Department of Geology Engineering, 90245 Makassar, Indonesia \\ ${ }^{2}$ Hasanuddin University, Department of Geophysics, 90245 Makassar, Indonesia \\ ${ }^{3}$ Hasanuddin University, Department of Civil Engineering Department, 90245 Makassar, Indonesia
}

\begin{abstract}
Rate of mineral deterioration in Tanjung Bunga Beach, Makassar city sediment, as a coastal city area that temporarily evolved with infrastructure development, through a Compaction test has found damage mineral from cracks, split and shatter. The aim of this research is to classify the compaction test from mineral as result texture breakage from compression test. Tanjung Bunga beach sediments based on grain size was classified from fine sand, medium sand and coarse sand. Petrographic analysis of 15 samples of in three drilling sites with 5 meters depth, found quartz mineral composition from $20-25 \%$, hornblende bertween $5-20 \%$, pyroxene $5-15 \%$, pagioclast $5-15 \%$, orthoclast $5-$ $15 \%$, biotite $10-20 \%$, and opaque minerals $10-25 \%$. Value of Compaction Test laboratory Fine Sand has 4 - 14.4 Div, Medium Sand has 6.7 - 20 Div, and Coarse Sand has 3.2 - 24 Div. Petrographic analysis after Mineral Compaction Test on fine sand was cracked up to $2-20 \%$, split $2-$ $12 \%$, and shattered $2-10 \%$, medium sand was cracked mineral up to $2-$ $15 \%$, split up to $1-13 \%$, and shattered up to $1-5 \%$, and coarse sand up to $1-10 \%$ cracked minerals, split up to $2-15 \%$, and shattered up to $2-7 \%$. High percentage of crack minerals were found in fine sand with low Compaction Test values and coarse sand with low crack mineral and high Compression Strength values. More cracked mineral was found in Quartz and no opaque minerals were shatter. Mineral pyroxene is founded as most shatter shape and orthoclase mineral with the most split shape.
\end{abstract}

\section{Introduction}

Tanjung Bunga beach area, Makassar area in development concept of "Water Front City", is part of "Waterfront Development" as development concept of coastal area with the construction of settlements infrastructure and coastal tourism. The burden in coastal sedimentary area may damage the minerals, change size and shape of minerals that will reduce the ability, formation strength of land, and coastal area functions.

Tanjung Bunga beach, characterized as spit beach were changing in gradual, vertical sediment composed by coastal sediment and a thickly fluvial-deltaic layer, a resistivity of 0.1 - 402 Ohm m, with value of $1.3 \Phi-2.4 \Phi$ (fine sand - medium sand), Coastal topography is relatively sloping and affected by the tides. Lands of coastal areas, generally

\footnotetext{
* Corresponding author: hamidumar@gmail.com
} 

kaolinites mineral types and quartz [2].

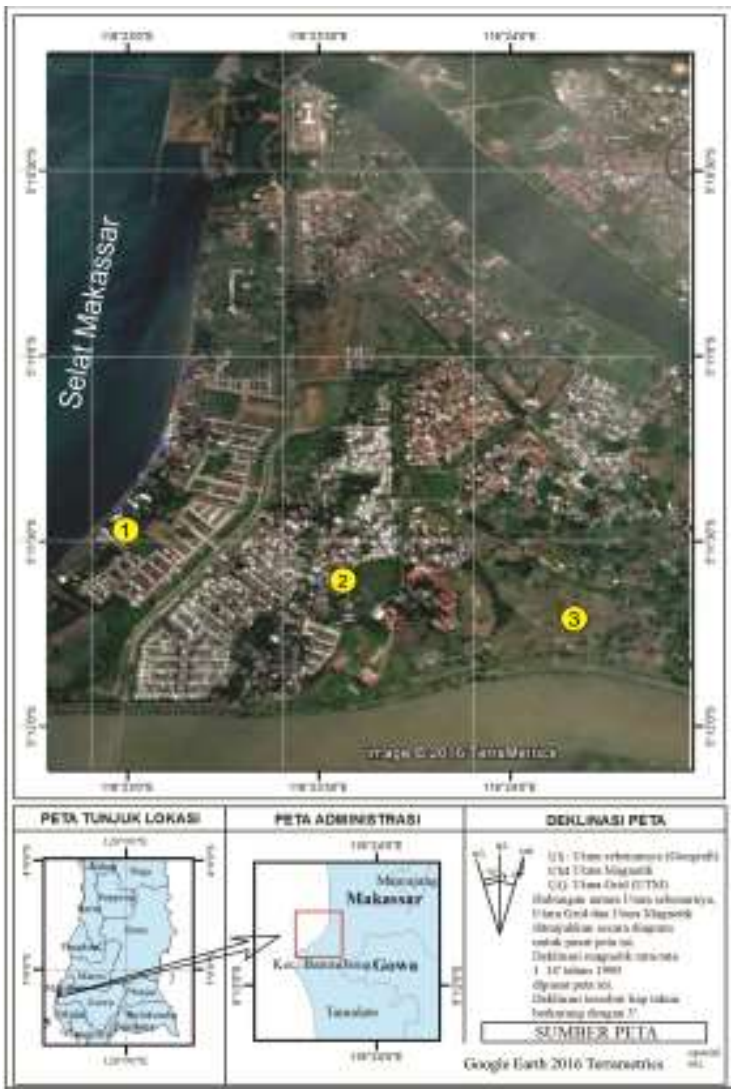

Figure 1. Map of research area and drilling point

Coastal plain of Tanjung Bunga is part of the Jeneberang River, containing minerals which are Quartz, Hornblende, Pyroxene, Orthoclase, Plagioclase, Biotite, and Opaque minerals in larger quantities than other minerals, with sizes from fine to coarse sand and rounded to sub rounded shape [3].

Quartz mineral ( $\mathrm{SiO} 2)$ is one of the main mineral constituents of sedimentary rocks, and as the most stable mineral found in clastic sedimentary rocks. Quartz minerals also found in coastal sediments and constitute up to $65 \%$ in sandstones and up to $30 \%$ in claystone [4]. The most composition of sandstones is a stable mineral, such as quartz, [5] which is part of the stable mineral group.

The aim of this research is to classify the compaction test from mineral as result texture breakage from compression test. Laboratory Compaction Test as one of the method of testing the ability and strength of the soil with loading, followed by analysis of the level of damage of minerals before and after loading with a magnification polarization microscope up to $100 \mathrm{x}$ conducted on thin section samples. In this study used 15 sediment samples at 3 points, which generally show the damage as well as changes size and shape surfaces of minerals from rupture, split to shattering, which is found on sediment samples of fine sand, medium sand and coarse sand. 


\subsection{Field research}

Determination of location at 3 drilling points, based on survey and analysis of coastal sedimentation profiles which is conducted until a depth of 5 meters by using Hand Auger. Sampling, observation and measurement of grain size on each sample are taken with the addition of depth every $50 \mathrm{~cm}$.

\subsection{Analysis of field data}

The samples were taken from 3 drilling points representing the top and bottom of each hole were 6 samples of fine-grained sediment, 4 samples of medium-sized sediment and 5 samples of coarse sand-size sediment, samples taken through sieve analysis using mesh size 60 , then dried and grouped according to the size of the mineral grains. Furthermore, it is cleaned from dirt and clay minerals, then do the preparation becomes "smear slide" and "Thin Section" with a thickness of $0.003 \mathrm{~mm}$, for petrographic analysis before loading and continued by testing loading with laboratory Compaction Test. Sediment samples from the loading test with Compaction Test are then repeat "Thin Section" preparation.

\subsection{Analysis of laboratory data}

Petrographic analysis of the sample before and after loading with laboratory Compaction Test, using a $50 \mathrm{x}-100 \mathrm{x}$ magnification polarization microscope, to determine the composition and amount of minerals. Which is broken from the crack level, split to shreds. The Smear Slide analysis of the sample was also observed using a 50x polarization magnification microscope to determine the grain size and grain shape of the mineral. Testing of loading with Compaction Test of the SNI standard laboratory was conducted to determine the value of change until the sample state had cracks occurring per unit time and level loading of samples.

\section{Result and analysis}

Sand is a non-clastic grain material came from a rock source, the sand is a naturally formed grain material and is composed of small sized materials comprising mineral and rock particles [6]. To observe the characteristics of soil, whether it is residual soil or sediment deposition, depends on two factors, which is; the natural characteristics of the soil particles themselves (such as the size, shape and composition of minerals) and the second one is particle content on the soil. In other words, these factors refer to the composition and structure [7].

The results of the research on sediment samples in the Tanjung Bunga area on Makassar showed that the minerals grain size was fine sand $(0.125-0.25 \mathrm{~mm})$, medium sand $(0.25$ $0.50 \mathrm{~mm}$ ) and coarse sand $(0.50-00 \mathrm{~mm})$., (Wentworth scale, 1922), in Folk (1974). Shape of the minerals is sub rounded - rounded, and the composition is Quartz $20-25 \%$ Biotite $10-20 \%$, Orthoclast 5-15\%, Pyroxene 5-15\%, Plagioclas 5-15\%, Hornblende 5-20\% and opaque minerals $10-25 \%$. Value of Compaction Teston fine sand (PH) 4 - 4.14 Div, medium sand (PS) 6.7 - 20 Div and coarse sand (PK) 3.2 - 24 Div.

The results of the loading test with CBR laboratory tests found the percentage of mineral damage from the cracking, diking, and crushing was not the same on the sediment of fine, medium, and coarse sands. Damage rate of cracked mineral is almost same in fine, 
lower than coarse sand. Change of mineral area before and after loading with CBR laboratory test is more on coarse sand than fine sand, there was significant change between value increases of CBR test with change level of mineral area.

Mineral composition are Quartz, Pyroxene, Hornblende, Plagioclase, Orthoclase, Biotite and Opaque mineral with different percentages on fine, medium and coarse sand sediment materials. Quartz minerals has the largest cracks percentage and Opaque mineral was the smallest. Orthoclase, Biotite and Plagioclases was the highest shatters minerals and the other minerals are generally dikes [3].

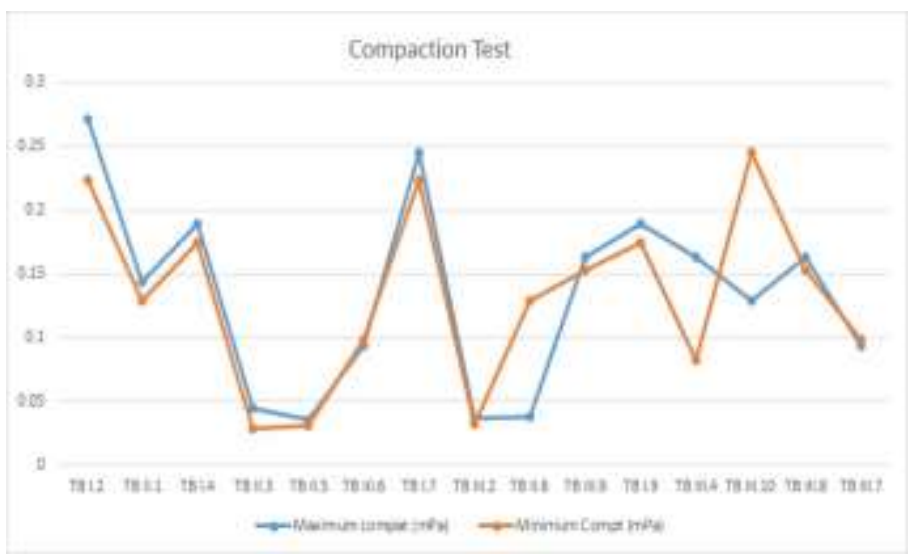

Figure 2. Value of loading of fine sand, medium sand, and coarse sand

The graphic chart show that Compaction laboratory test value indicate increase from low to high on fine sand, medium sand, until coarse sand, thereby Compaction laboratory test on coarse sand is higher than fine sand and medium sand. On the graphic show that relationship between load value Compaction laboratory test is significance with mineral grain size from fine sand, medium sand until coarse sand.

According to mineral breakage stage analysis from crack, torn apart until broken after load test with Compaction laboratory Test for sample group from fine sand, medium sand until coarse sand, there are mineral breakage percentage from crack, torn apart until dike, different on fine sandm medium sand and coarse sand, there are relationship between mineral breakage percentage with Compaction laboratory Test (figure 3, 4 \& 5).
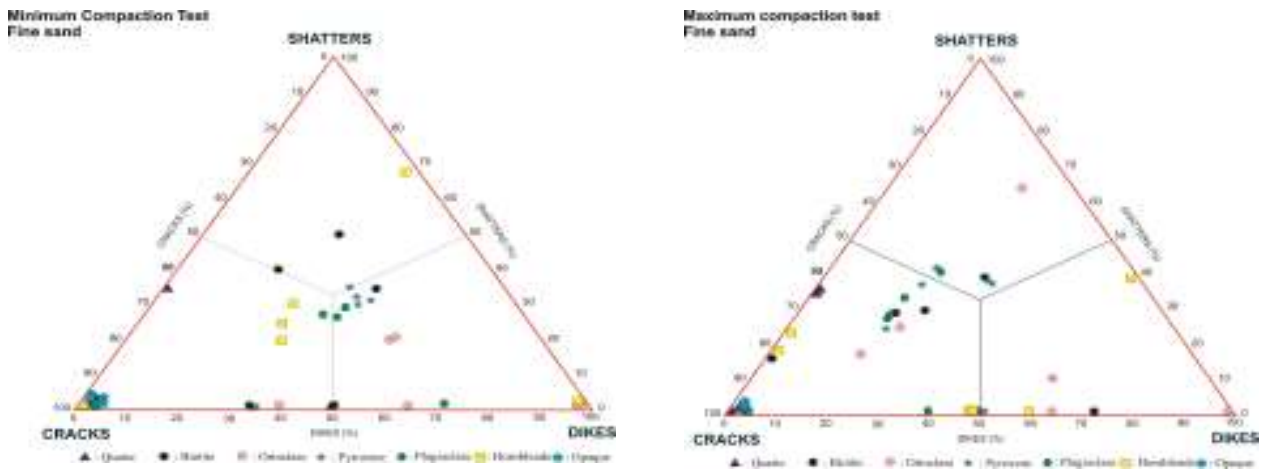

Figure 3. Damage percentage of fine sand 


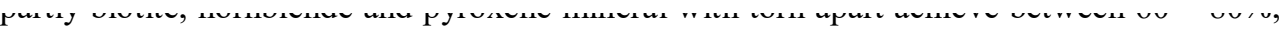
on opaq mineral, crack is less than $45 \%$. Mineral with broken between $45-85 \%$ torn apart and crack achieve $20-50 \%$ is orthoclase. Shatters mineral between $60-80 \%$ is partly on Biotite, Pyroxene mineral, quartz and orthoclase mineral achieve less than $60 \%$.
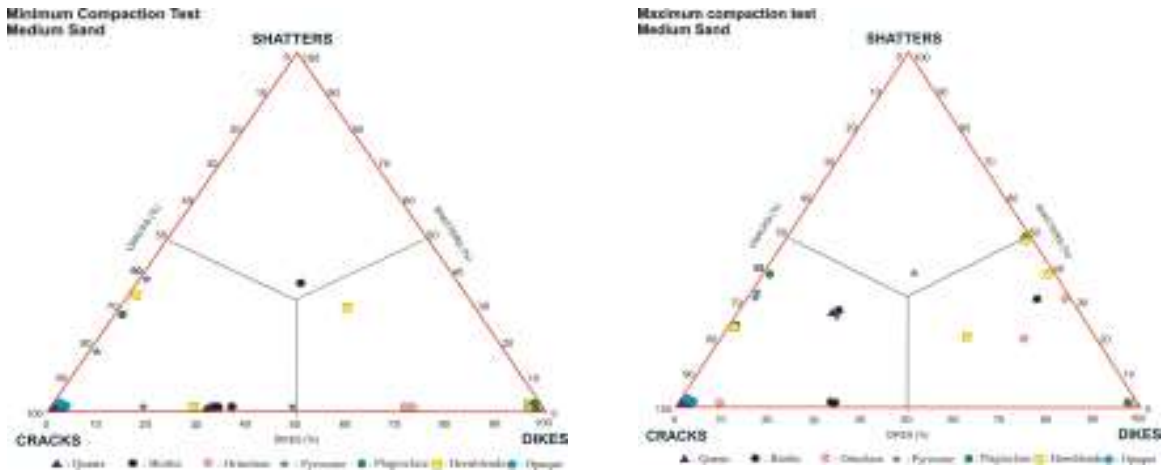

Figure 4. Damage percentage of medium sand

The mineral Quartz mineral damaged achieve between $32-52 \%$, while mineral Plagioclase and hornblende damaged achieve between 50-100\%. Cracked minerals reach 65 - 100\% consisting of quartz minerals, Plagioclase and, hornblende and Opaque Minerals cracked up to $35 \%$, as well as on Orthoclase minerals that dikes $100 \%$. Biotite and Orthoclase are crushed up to $45 \%$. Mineral Biotite, Pyroxene and Plagioclase. Which dikes in between 30-70\%, from the amount of defective biotite minerals reaches $67-100 \%$, whereas in the mineral pyroxene up to $53-100 \%$.

In the encountered mineral cracking reaches 65 - 100\% consisting of Quartz mineral, Plagioclase, Hornblende and Biotite. Quartz damaged achieve between 40-80\%, whereas the Plagioclase minerals and mineral Hornblende total damage at between 50-100\%.

In mineral Biotite, Pyroxene and Plagioclase are dikes between 40-60\% and the crack reaches $62-85 \%$. Damaged biotite minerals reach between $67-100 \%$, whereas in mineral pyroxene reach $100 \%$. In Biotite and Plagioclase minerals, which have been crushed to $50 \%$, and Orthoclase minerals reach $100 \%$. Another thing encountered in the mineral Orthoclase also dikes between $60-100 \%$, even up to $60 \%$ over $60 \%$. In opaque minerals, gain rupture to $35 \%$.

There are torn apart mineral achieve $50-100 \%$ consist of quartz, plagioclase, pyroxene and biotite mineral. Along with $20-50 \%$ torn apart are biotite and pyroxene mineral. Plagioclase $50-80 \%$ torn apart and crack achieve $50-75 \%$, and this mineral broken until $50 \%$. On quartz mineral damage total achieve $40-80 \%$, on plagioclase and hornblende mineral damage total achieve $50-100 \%$. On biotite mineral damage total is $67-100 \%$, on pyroxene and plagioclase mineral damage total achieve $100 \%$. On opaque mineral that crack until $100 \%$ from mineral damage total $45 \%$.

This data show that broken mineral amount is more happen on fine sand and torn apart mineral on coarse sand. There are high crack mineral amount on fine sand with Compaction Test value lower and coarse sand with low crack mineral amount with high Compaction Test value. Quartz mineral much more that crack and no opaque mineral that broken, pyroxene mineral much more broken along with orthoclase mineral much more torn apart.

Triangle analysis above show that between Compaction laboratory test with damage mineral level that show high CS test value increase on coarse sand, inversely proportional with crack and broken mineral much more on fine sand with low CS test value. That thing show that Compaction Test value on coarse sand higher than fine sand and medium sand, 
This thing support by geotechnic index characteristic different from soil that almost multiple diverse and mineral proportion different [2] also give different result, along with change degree that change because of load depend on gradation, soil component, mineral reduction characteristic, amount and load average and tenacity degree from particel individual load set to constant, porocity change average, pore number and weight unit depend on soil permeability.
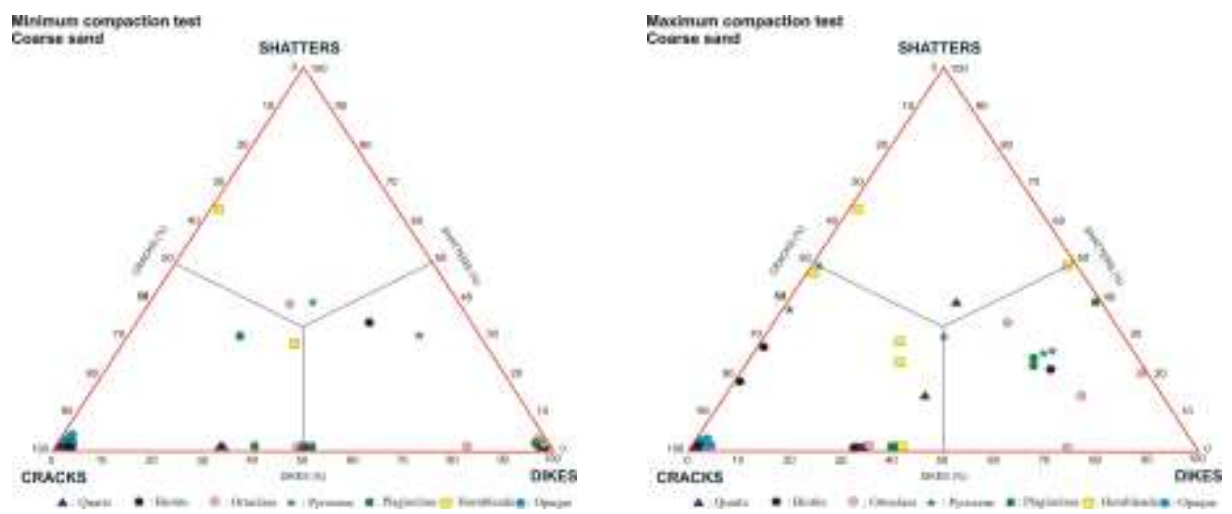

Figure 5. Damage percentage of coarse sand

Particel individual here is minerals that show microstructural characteristic, like mineral composition, grain size, and damage on mineral, considerable by some writer to become micostructure parameter to determine sedimen and rocks mechanic habit characteristic. Microstructure point to characteristic on observed surface in thin section with using microscope on milimeter scale and some writer using texture and microstructure as synonim [8].

Accroding to petrography analysys mineral damage level find on this research from crack, torn apart and broken on micro $\mu \mathrm{m}$ scale with 50x zoom until 100x (Figure 6), and mineral physical change on this matter as mineral area wide (Figure 7).
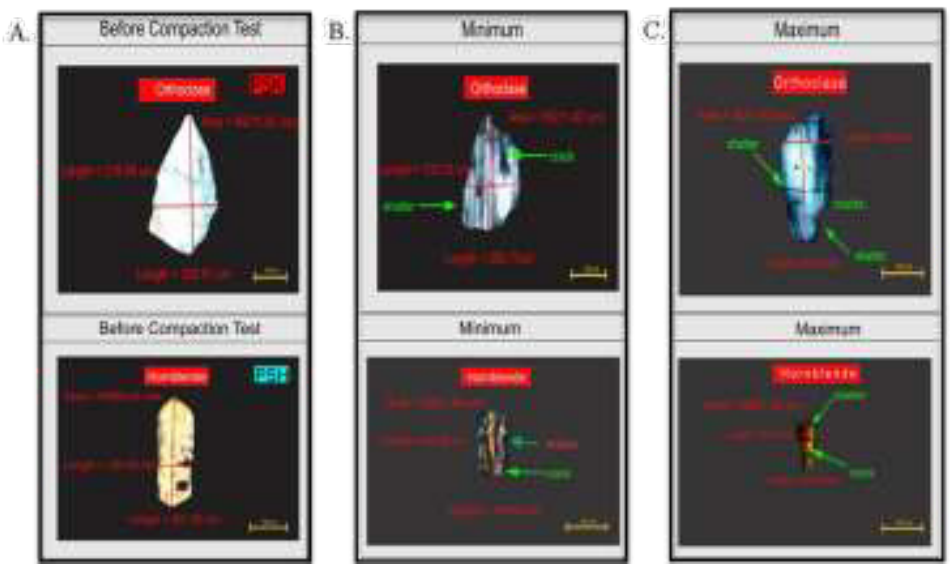

Figure 6. Condition from mineral Orthoclase and Hornblende before compaction test (A), mineral Orthoclase and Hornblende in minimum test (B), mineral Orthoclase and Hornblende in maximum value test (C). 

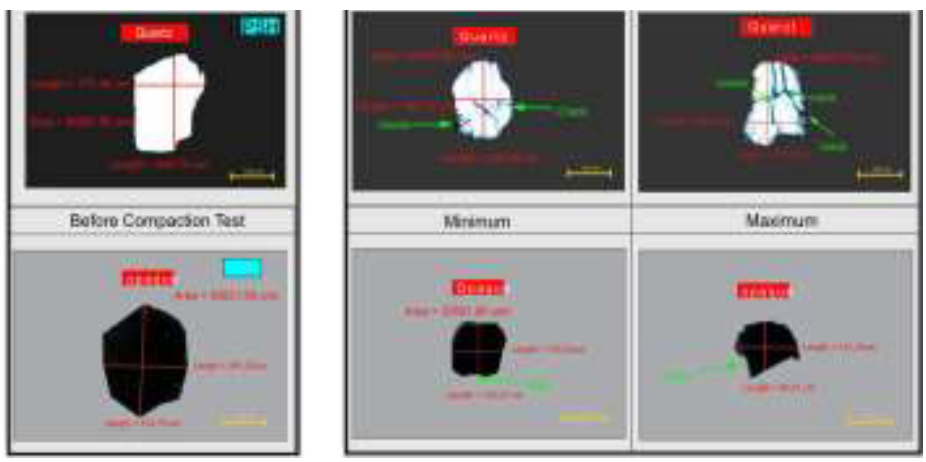

Figure 7. Photomicrograph of monomineral Quartz and Opaque mineral before barrier (A) and after barrier (B) in 100x magnification

According to mineral size change on thin section fine sand sample, medium and coarse, before and after Compaction Test load, show mineral are wide size change on fine sand lower than medium and coarse sand (Fig $6-7$ ).

On the graphic difference mineral area wide size change from before Compaction Test load and after Compaction Test load, show that difference area wide size quartz and opaque mineral lower than other, this thing show that quartz and opaque mineral have hardness level higher than other, so that load value on Compaction Test related positive on the mineral. This research result also show that effect of load with Compaction Test give influence on mineral damage lower than its percentage on coarse sand with high Compaction Test value and mineral damage with high percentage on fine sand with low Compaction Test value.

Table 1. Difference change of mineral size area before and after barrier with CS laboratory test

\begin{tabular}{|l|r|r|r|}
\hline Mineral & \multicolumn{1}{|c|}{ Fine Sand } & \multicolumn{1}{|c|}{ Medium Sand } & Coarse Sand \\
\hline Quartz & 3009.97 & 2300.2 & 1006 \\
\hline Biotite & 2189.3 & 2020.93 & 3001.51 \\
\hline Orthoclase & 4160.3 & 2221.44 & 999.99 \\
\hline pyroxene & 1463.01 & 3363.57 & 4948 \\
\hline Plagioclase & 2017 & 4395 & 1482.29 \\
\hline Hornblende & 1406.4 & 2399.52 & 11015 \\
\hline Opaque & 2712.97 & 1132.36 & 2964 \\
\hline
\end{tabular}

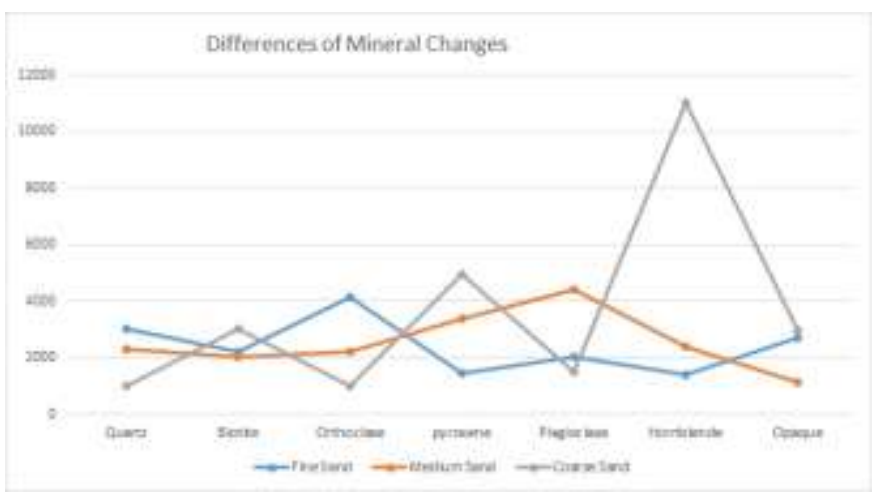

Figure 8. Difference graph of mineral size 


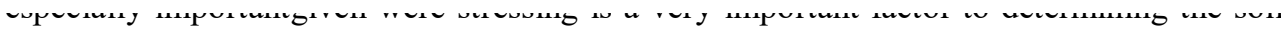
or sediment characteristics and refers to normal soil and excessively of consolidated soil material [9].

\section{Conclusions}

The result of barrier test with Compaction from laboratory test showed the damage percentage of minerals from cracked, split, and shattered are not same on the fine sand, medium sand, and coarse sand sediment. Damage level of cracked and shattered minerals in fine sand is much higher than in coarse sand were Compaction Test value on fine sand is lower than the coarse sand. mineral changes area before and after barrier with Compaction Test laboratory, more occurred in coarse sand than fine sand, the increase of Compaction Test value with change level of mineral area.

Mineral composition has aree Quarts, Pyroxene, Hornblende, Plagioclase, Orthoclase, Biotite and Opaque mineral with different percentages on fine, medium, and coarse sand sediments. In Quartz minerals with has high crack and opaque mineral was lower percentage. Biotite, Plagioclase, and Orthoclase are minerals whose has highest shattered percentage were the other minerals are dikes.

\section{Acknowledgements}

Thank you for Werdi, Bayu and Irfan who has contribution during this research.

\section{References}

1. Langkoke, R., Apriani, S. Sebaran Mineral Berat Endapan Pasir Pantai Tanjung Bunga Kecamatan Mariso. Prosiding Hasil Penelitian Fakultas Teknik Unhas. ISBN: 978-979127255-0-6. (2010).

2. Langkoke, R., Rochmanto. B. Pengaruh Karakteristik Pantai Estuari Makassar Terhadap Perkembangan Kota Pantai. Prosiding Seminar Nasional: Teori dan Aplikasi Teknologi Kelautan 2010.ITS - Surabaya. ISSN: 1412 - 2332, 9 - 10 Des. 2010. (2010).

3. Umar, H. and Al Fuad. Study on Characteristic and Distribution of Mineral Deposits of Sediment At Jeneberang Estuary of Gowa, South Sulawesi Province, Proceeding of the 1st, International Conference Civil and Infrastructure. (2015).

4. Boggs, S. Principle of Sedimentology and Stratigraphy.3 ed. Prentice Hall, Inc.Uper Saddle River: New Jersey 07548. (2001).

5. Pettijohn, F. J. Sedimentary Rocks.3rd edition. Harper \& Row Publishers Inc, New York. (1975).

6. Roy, T. K. Influence of sand on strength characteristics of cohesive soil for using as subgrade of road, Proceedings - Social and Behavioral Sciences 104 (2013) 218-224 (2013)

7. Wesley, L. Behaviour And Geotechnical Properties Of Residual Soils And Allophane Clays. Obras y Proyectos 6. 5-10. (2009).

8. Duarte, M.T., H. Y. Liu, S. Q. Kou, P. -A. Lindqvist, and K. Miskocsky., 2005. Microstructural Modeling Approach Applied To Rock Material. JMEPEG 14: 104-111. (2005) 


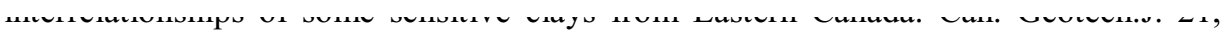
(1984) 530-540. (1984).

10. Suriamihardja, D.A, Samang, L, Ria, Ulva., Umar, Hamid. Effect of Barrier On Mineral Change In Tanjung Bunga Beach Makassar. International journal of civil engineering and technology (IJCIET) vol. 8, issue 7, july 2017,pp, 911-919. (2017). 